\title{
Occurrence of Sclerotium rolfsii causing collar rot to Peperomia glabella in Argentina
}

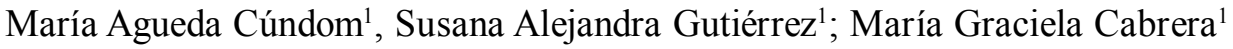

${ }^{1}$ Cátedra de Fitopatología, Facultad de Ciencias Agrarias, Universidad Nacional del Nordeste, Sargento Cabral 2131, (3400) Corrientes, Argentina. Autor para correspondência: María A. Cúndom (macundom@yahoo.com.ar)

Data de chegada: 18/04/2013. Aceito para publicação em: 30/03/2013.

Peperomia glabella A. Dietr., native to South America, is an ornamental plant that belongs to the family Piperaceae. It has been commonly cultivated in private gardens and commercial greenhouses at Corrientes Province (Argentina). In 2010 , peperomia plants with rot stems followed by premature death were observed (Figure 1). Symptomatic stems were collected and examined with the naked eye and the microscope. Some samples were incubated under wet chamber conditions and kept in the laboratory at room temperature $\left(25-27^{\circ} \mathrm{C}\right)$, while the others were surface-sterilized for $1 \mathrm{~min}$ by soaking in $1.5 \%$ sodium hypochlorite solution and plated on potato dextrose agar (PDA). Plates were incubated at $25^{\circ} \mathrm{C}$ for 10 days.

Identification was done based on morphological characteristics. The fungus developed white radial growth mycelia, with hyaline, thin and septed hyphae, which presented scattered branching and characteristic fibulae. On these mycelia, the fungus also formed small, white, globose sclerotia, which subsequently turned from light brown to dark brown and were $0.6-1.2 \mathrm{~mm}$ in diameter. Based on these characteristics and morphometric features, the pathogen was identified as Sclerotium rolfsii Sacc.

Pathogenicity tests were conducted with one isolate. Mycelial plugs from the colonies of the isolate growing on PDA were placed on the stem base with or without shallow wounds of each peperomia plant. Control plants were inoculated with noncolonized PDA plugs. All plants were enclosed in plastic bags. The latter were sprayed with water to maintain the high humidity in the laboratory at room temperature $\left(24-27^{\circ} \mathrm{C}\right)$. After $48 \mathrm{~h}$, the bags were removed and the plants were kept in a greenhouse at $25-32^{\circ} \mathrm{C}$.

Symptoms similar to those observed in private gardens and commercial greenhouses were evident in the inoculated plants, which showed basal stem rot after five days and died after 15 days.

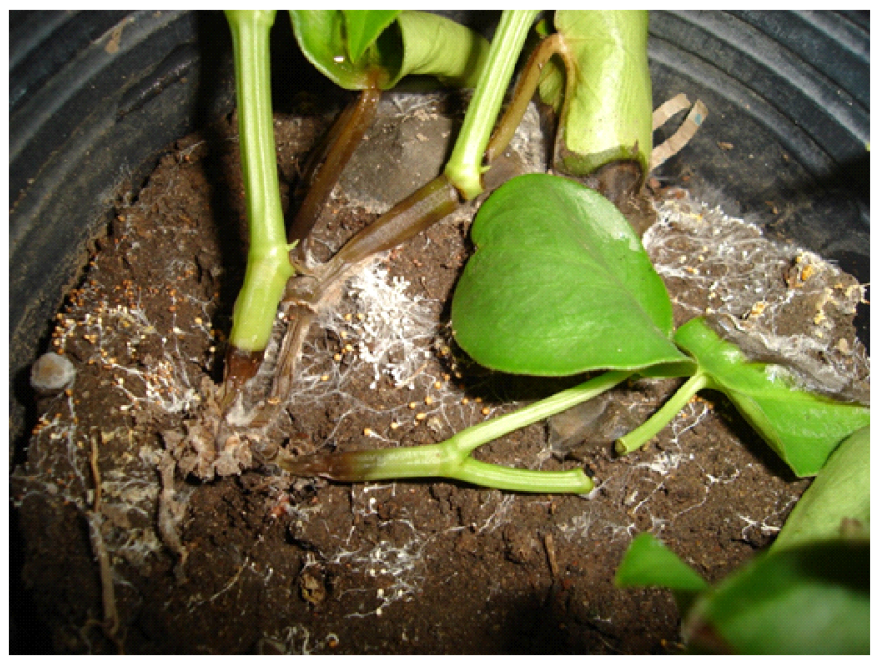

Figure 1. Symptoms of collar rot on Peperomia glabella caused by Sclerotium rolfsii.

Subsequently, the fungal pathogen was identified and reisolated from inoculated plants. It was characterized as Sclerotium rolfsii Sacc based on the above-mentioned morphological characteristics.

Sclerotium rolfsii, a soil-borne fungal pathogen, causes diseases to a wide range of plants. For peperomia, it is a particular destructive pathogen during vegetative propagation in a greenhouse, or even under warm and wet environmental conditions (Alfieri SA Jr, Knauss JF. Plant Pathology Circular No 202. Fla. Dept. Agric. \& Consumer Serv. 1979). It has been reported for several species in Argentina (www.fitopatoatlas.org.ar/ Access February 18, 2013), but this is the first report of $S$. rolfsii on P. glabella in Argentina. 